\title{
BUILDING STONES \\ USED IN EARLY MEDIAEVAL EDIFICES OF KRAKOW AND GEOLOGY OF THE AREA
}

\section{Jan BROMOWICZ \& Janusz MAGIERA}

\author{
AGH University of Science and Technology, Faculty of Geology, \\ Geophysics and Environment Protection; \\ al. Mickiewicza 30, 30-059 Krakow, Poland; \\ e-mail: bromow@geol.agh.edu.pl,magiera@geol.agh.edu.pl
}

\begin{abstract}
The early mediaeval period witnessed a considerable breakdown in masonry techniques and in architecture in the Polish territory: the application of stone and developing of skills of shaping rocks into regular cuboid stone bricks.

Only local stones quarried within a distance of ca. $15 \mathrm{~km}$ from Krakow were used in early mediaeval edifices in the city. They were: two varieties of limestones (Upper Jurassic) and three varieties of sandstones of the Carpathian flysch (Cretaceous to Palaeogene). Sedimentary environments (facies) and post-sedimentary processes determined compactness, block divisibility and workability of stones, which, further on, determined their application. Thin bedded sandstone and platy limestone yielded easily workable and relatively small (few to a dozen of centimetres in length) and quite regular bricks used in the earliest buildings. Rocky limestone was a source of irregularly shaped clumps used initially as a filler of walls erected in the opus emplectum technique. Later, it was used also for cutting larger (few tens of centimetres), more regular blocks. Bedded limestone was a good material for obtaining larger (a dozen or two dozens of centimetres) regular bricks used widely throughout the whole early mediaeval period. Blocks ( 2 or more metres in length) of soft dimension Carpathian sandstone were used for shaping and carving large elements: tombstones, columns, volutes, epitaphs, etc.

Techniques of quarrying and stone working developed considerable with time. Initially, slope scree and stone from demolished older ramparts were used. Later, quarries reached deeper beds which yielded larger bricks and blocks. Stone sources "migrated" with time too. The earliest places of excavation were located within the city, e.g. on the Wawel, Skałka and Krzemionki hills. When those deposits were exhausted, mining moved to more distant spots.
\end{abstract}

Key words: Pre-Romanesque and Romanesque buildings, Wawel Hill, dimension stone, masonry, Jurassic limestone, Carpathian sandstone 


\section{INTRODUCTION}

Archaeological, architectonic and historical investigations on historical buildings deal mainly with age, stratigraphy, style, shape etc. Material used for the construction is commonly described rather briefly. In the case of stone its petrographic type (limestone, sandstone, granite etc.) is mentioned, sometime with its regional name (e.g. Portland, Pinczów, Carrara etc.). Very rare petrographic studies were performed on stones used in old constructions in Krakow. Petrography (mineral composition, structure, texture) determines physical and mechanical properties, which, further on, determine their application, provenance and sources - region, locality and even a quarry. Such studies are important for reconstructing and understanding past architectonic, handicraft (masonry), transport, economic, and other similar problems. They yield also important hints indicating the stones for replacements in reconstructions and optimising conservation techniques (e.g.: Bromowicz \& Magiera 2003, 2006, 2009).

The present study aims at such complex examination of stones used in early mediaeval buildings in Krakow. Petrographic and geometric (shape and size) characteristics of stones is presented. Petrography gives a base for finding location of quarries of stones, their shape and size allows for conclusions on the development of art of masonry.

\section{METHOD}

Historical buildings of Krakow have been more intensely and systematically reconstructed and conserved since the beginning of the twentieth century. This process has considerable intensified since 1980s. It was accompanied by vast archaeological excavations (e.g.: Firlet \& Pianowski 1985, Pianowski 1991, 1994). All this resulted in increased accessibility to the fragments of buildings normally hidden in the earth or covered by plaster. Examinations of stones (observations, measurements, sampling) carried out in situ were a basis for the study. Only in a few cases measurements were done on drawings attached to the publications (Hendel \& Kopera 1906, Rojkowska \& Niewlada 2005).

Observations in situ comprised macroscopic determination of petrography (mineral composition, structure, and texture), symptoms of deterioration and measurements of visible edges of stone elements (regular blocks and bricks, irregular clumps). Statistic of stone shape and size was calculated next and used for analysis of some trends and rules in the art of masonry and quarrying and their change in time.

Samples for petrographic examinations were taken wherever possible, with respect to the historical value of the objects sampled. In most cases they were small (a few milimetres to a few centimetres in size) chips. In a few places it was possible to take larger (up to $10 \mathrm{~cm}$ in size) stone clumps from reconstructed foundations or walls. Sampling sites were photographed, marked on inventory drawings and described. Samples were examined under the stereoscopic microscope in the incident light and then in the transmitted polarized light, which is a standard method in microscopic petrography. Results of the examinations of 
the samples taken from historical buildings were finally compared to petrographic database of original stones collected from the quarries.

\section{GEOLOGY}

To describe geology of the Krakow area in a context of provenance of building material it is necessary to take into account an area stretching well beyond Krakow early settlement and even beyond the area of the contemporary Krakow, i.e. area where building stones cropped out at the Earth's surface and attracted an attention of early architects and constructors (Fig. 1). The geology of the area was studied by many geologists, e.g. Rutkowski (1989, 1993), R. Gradziński \& M. Gradziński (1994), Burtan (1954, 1984) and Książkiewicz (1972). The present account is based essentially on their works.

Three major geological structures occur there. They are, from South to North: Carpathian Mountains, fore-Carpathian through and Palaeo-Mesozoic platform. The latter comprises strongly folded Palaeozoic basement topped with gently NE dipping Mesozoic monocline (Krakow-Silesian Monocline). In its western part Upper Jurassic limestone occur at the surface forming Krakow-Częstochowa Jura. Further NE Upper Cretaceous marls of the Nida Depression dominate. Southern part of the platform stretches far below the Carpathians that thrust over it. Directly at the Carpathians front a deep foremontane through developed. Its width varies from just $2 \mathrm{~km}$ in Krakow (so-called Krakow lock) to nearly $20 \mathrm{~km} \mathrm{~W}$ of Krakow. Carpathians are Alpine (flysch) fold-and-thrust belt formed of several nappes overthrust northwards and built mainly of various sorts of sandstones and shales with subordinate intercalations of marls, limestones and other sedimentary rocks.

Upper Jurassic limestones and Carpathian sandstones were used as main building material in Krakow. The former represent several facial varieties, which originated in different marine environments. This determined their hardness and block divisibility, which are essential features of the building stones. Massive and hard rocky limestone represent a bioherm build-up (c.f. Matyszkiewicz 1997), with no bedding and with scarce and irregular joint surfaces. Bedded limestone (with cherts), which is a product of mechanical deterioration of bioherms and sedimentation of detritic material at their foothill, is, in turn, well bedded and splits rather easily to more regularly shaped "bricks". Their hardness is similar to rocky limestone. Platy and chalky limestones sedimented consequently further from the bioherms. The former splits perfectly into thin regular plates and yields building material commonly searched for good hardness. Chalky limestone has never been widely used due to not satisfactory hardness and limited extent.

Building sandstones were taken essentially from two nappes: Silesian and Sub-Silesian. They were: Grodziszcze, Gaize, Lgota, Istebna and Ciężkowice formations. Three former formations contain similar thin- or medium-bedded $(10-30 \mathrm{~cm})$ sandstones, compact, grey-coloured when fresh, dark-brown when weathered, fine- to medium-grained, and flat- or wavy laminated, thus easily splitting to thin plates. Shale interbeddings are normally frequent and thick. Thick (up to $1 \mathrm{~m}$ ) sandstone medium- to coarse-grained, dark-grey to yellowish and brownish (when weathered) layers are rare. 

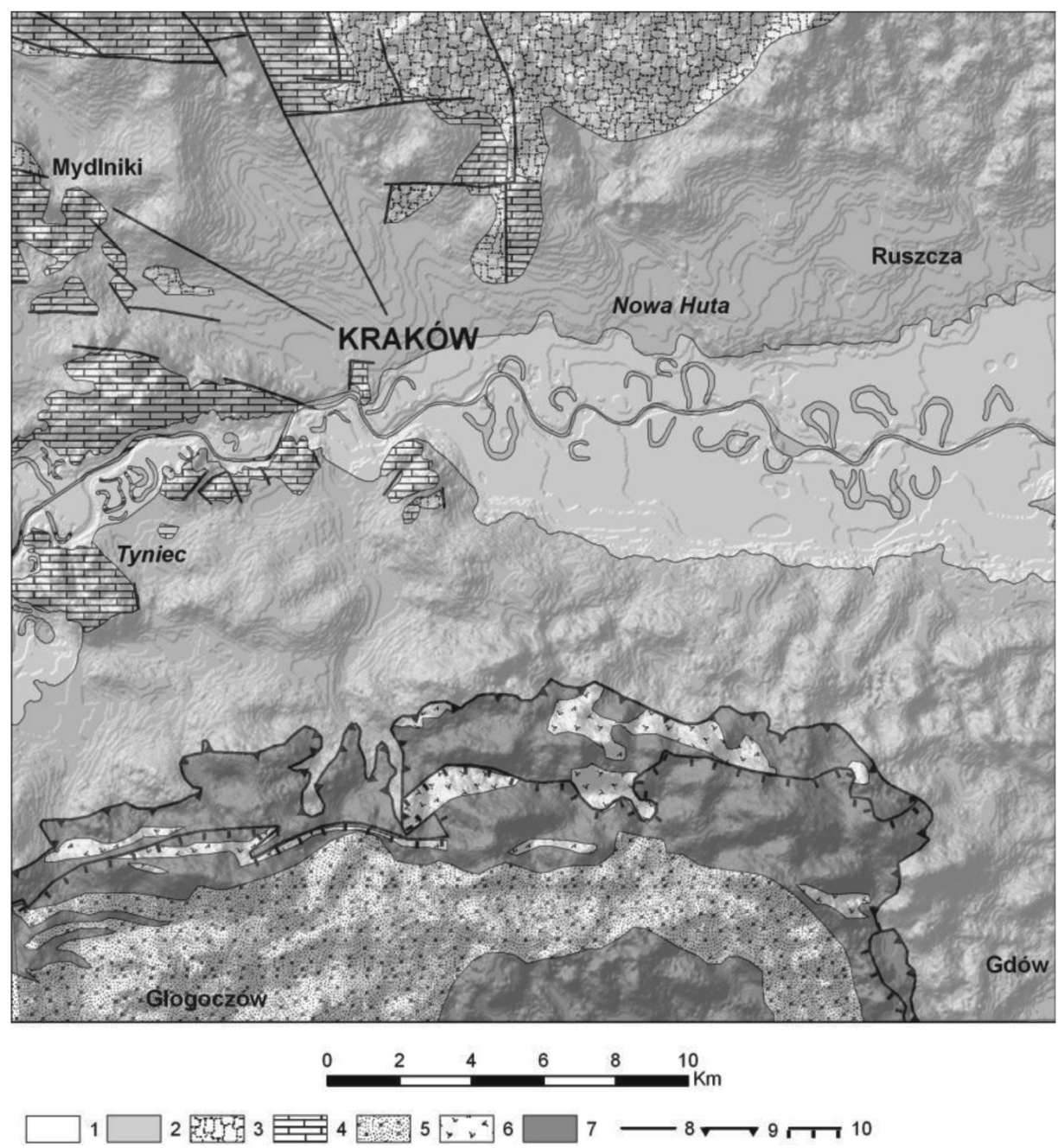

Fig. 1. Geology of the Krakow area (based on Geological map of Poland, 1:200 000, Magiera \& Michalczyk 2000): 1 - Vistula River alluvium; Carpathian Foredeep: 2 - clay, silt, sand and sandstone (Neogene); Krakow-Silesian monocline: 3 - marls and marly limestone (Upper Cretaceous), 4 - bedded and rocky limestone (Upper Jurassic); Carpathian flysch: 5 - Istebna sandstone and shale (Upper Cretaceous - Palaeogene), 6 - Gaize sandstone (Lower Cretaceous), 7 - other flysch sandstone, shale, marl and cherts; 8 - faults, 9 - front of the Carpathians (Sub-Silesian nape), 10 - front of the Silesian nape

Istebna and Ciężkowice sandstones represent typical "sandy" Carpathian flysch. Their layers are up to $5 \mathrm{~m}$ thick (most frequently 1-2 m). Grain is coarse to very coarse (grit), with frequent feldspars (arkose sandstone). Scarce matrix is essentially clayey with admixture of silica. Carbonates are usually absent. They are light-grey to light-yellow coloured, brown or red- 
-brown when weathered. They often form tors on slopes or ridges (Z. Alexandrowicz 1978). There are no sources of building stones known in the Carpathian Foredeep in close vicinity of Krakow.

\section{EARLY MEDIAEVAL EDIFICES IN KRAKOW}

Stone buildings appear in Krakow in the late tenth and early eleventh centuries. Most of them are located on the Wawel Hill (Fig. 2). Buildings located beyond the Wawel Hill are exclusively of ecclesiastic character (Fig. 2).

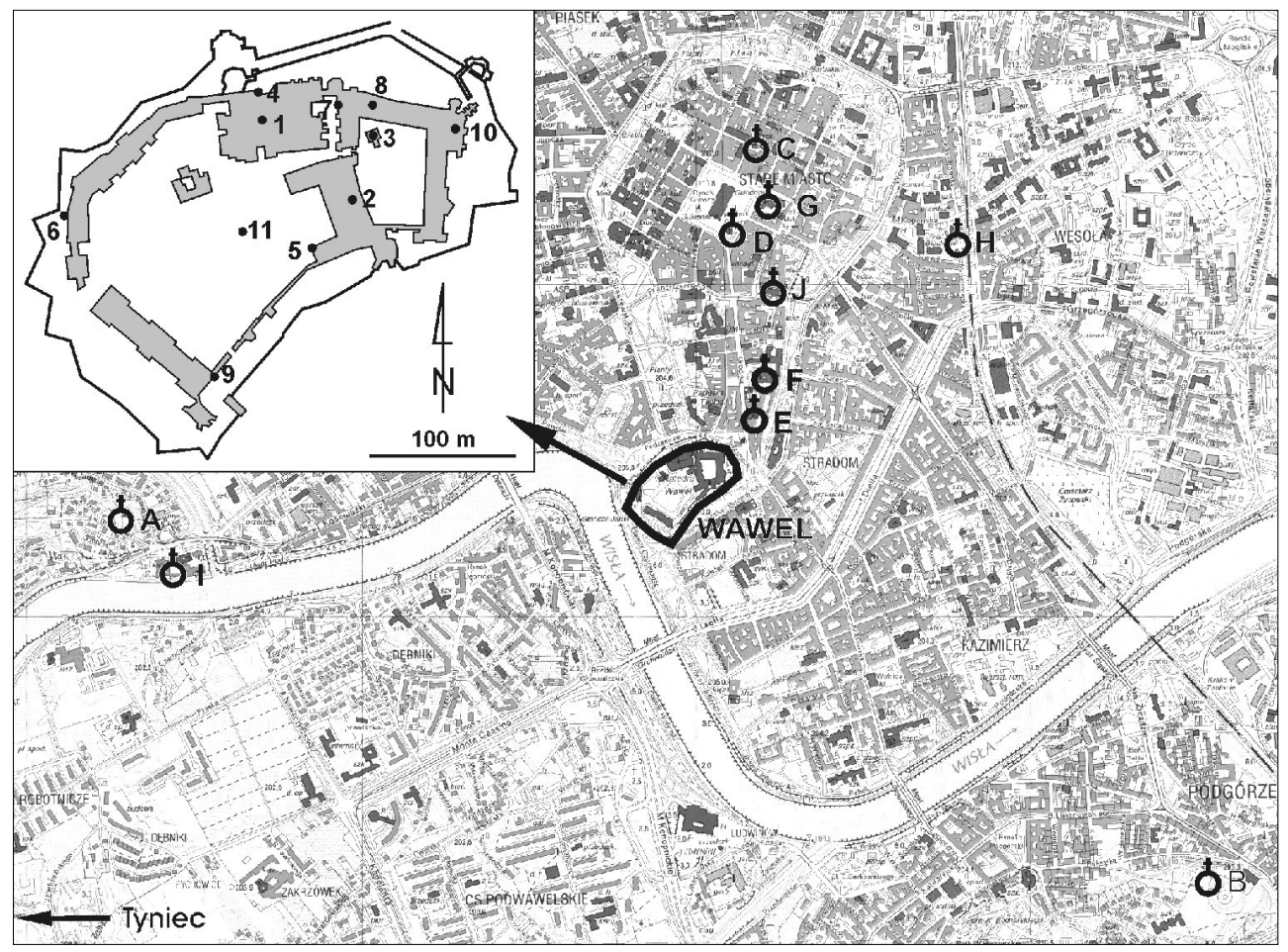

Fig. 2. Location of early mediaeval edifices in Krakow (after Bromowicz \& Magiera 2008, modified). Churches: A - St. Salvatore, B - St. Benedict, C - St. John, D - St. Adalbert, E - St. Andrew, F - Mary-Madeleine, G - St. Mary, H - St. Nicholas. Convents: I - Norbertine, J - Dominicans and Franciscans, Benedictine (in Tyniec). Edifices of the Wawel Hill (in inset): 1 - Pre-Romanesque cathedral known as "Chrobrowska" and Romanesque cathedral known as "Hermanowska", 2 - church of St. Felix and Adauct (or Blessed Virgin Mary), 3 - quadrangular building with corridor, 4 - church-baptistery and younger cathedral on its site, 5 - rotunda (or church) "B", 6 - western gate (by the Smocza Jama cave), 7 - church allegedly under the invocation of St. Gereon call, 8 - palladium (chamber with 24 columns), 9 - church near Sandomierska tower, 10 - defence tower (called Stolp), 11 - St. Michael's church 
Earlier - Pre-Romanesque and later - Romanesque buildings are distinguished among them (Kozieł 1998). Walls of the former were built of rough blocks of sandstone and bricks of platy limestone. Irregular blocks of limestone were used in foundations and as a filler of walls erected in the opus emplectum technique (sides of the wall are formed of regularly shaped stones with smooth external faces while a gap between them is filled with irregular stone clumps). In many cases younger buildings constructed of more regular blocks replaced earlier ones located in the same place.

\section{STONES USED IN EARLY MEDIAEVAL EDIFICES IN KRAKOW}

Investigations on types of stones as well as shapes and size of their blocks used in early mediaeval buildings in Krakow were carried out by, e.g.: Firlet \& Pianowski $(1978,1985)$, Pianowski (1991) and Kozieł (1998). The latter distinguished three types of stones: plates of sandstone and plates of limestone used in external faces of walls and irregular pieces of limestone used as wall fillers and material for foundations. Two more types were found recently by the authors of the present paper: thick plated compact sandstone and soft, dimension sandstone.

Actually, five main types of stone shaped blocks can be found in early mediaeval edifices in Krakow (Bromowicz \& Magiera 2008 and 2010):

1) hard, thin platy sandstone,

2) thin platy limestone,

3) hard, thick platy sandstone,

4) irregularly shaped limestone,

5) soft blocky (dimension) sandstone.

\section{Hard, thin platy sandstone}

Hard, thin platy sandstone was found in the church of St. Felix and Adauct, in the western Wawel castle gate by the Smocza Jama cave and in the only sample taken from the "Quadrangular edifice with corridor" (Bromowicz \& Magiera 2009).

\section{Petrography}

They are usually fine-grained, sporadically medium- or coarse-grained, grey with greenish shadows, with thin brown or red-brown weathering crust. Visible is fine laminated structure. Quartz, feldspars, micas and rounded fragments of limestone and metamorphic rocks as well as glauconite, pyrite, pieces of fossil plants and coal can be seen in microscope. Needles of both, siliceous and carbonate sponges are frequent and make described stone a gaize or a gaize sandstone (sensu Caileux 1929). Grains are bound with calcitic-argilicaeous cement with some admixture of silica (opal, chalcedony or quartz matrix).

254 measured elements revealed average thickness of $5.4 \mathrm{~cm}$, average length of $22.6 \mathrm{~cm}$ (Tab. 1). 
Table 1

Size of hard thin and thick platted sandstone elements in early mediaeval edifices in Krakow

\begin{tabular}{|c|c|c|c|c|c|c|}
\hline \multirow{2}{*}{$\begin{array}{c}\text { Variety } \\
\text { of sandstone }\end{array}$} & \multirow{2}{*}{ Edifice } & \multirow{2}{*}{$\begin{array}{c}\text { Number } \\
\text { of } \\
\text { measurements }\end{array}$} & \multicolumn{2}{|c|}{ Height $[\mathrm{cm}]$} & \multicolumn{2}{|c|}{ Length $[\mathrm{cm}]$} \\
\hline & & & average & $\begin{array}{l}\text { standard } \\
\text { deviation }\end{array}$ & average & $\begin{array}{l}\text { standard } \\
\text { deviation }\end{array}$ \\
\hline Thin platted & $\begin{array}{c}\text { church of St. } \\
\text { Felix and Adauct }\end{array}$ & 245 & 5.4 & 2.8 & 22.6 & 10.9 \\
\hline \multirow{3}{*}{ Thick platted } & $\begin{array}{l}\text { church } \\
\text { of St. Gereon } \\
\text { (walls) }\end{array}$ & 92 & 13.5 & 6.6 & 22.3 & 13.6 \\
\hline & $\begin{array}{c}\text { church } \\
\text { of the Tyniec } \\
\text { Abbey } \\
\text { (walls of apse) }\end{array}$ & 114 & 10.4 & 3.2 & 23.8 & 9.5 \\
\hline & $\begin{array}{l}\text { church } \\
\text { of the Tyniec } \\
\text { Abbey (walls } \\
\text { of presbytery) }\end{array}$ & 222 & 13.4 & 7.6 & 26.2 & 15.7 \\
\hline
\end{tabular}

\section{Thin platy limestone}

Thin platy limestone was described and sampled in the Chrobrowska cathedral, $\mathrm{N}$ wall of the annex to the church of St. Felix and Adauct and in W Wawel gate (Bromowicz \& Magiera 2003, 2009). They have white, grey-yellowish or light-brown colour.

\section{Petrography}

Soft thin platy limestone has pelitic texture. Micrite calcium carbonate forms uniform, semi-transparent (in transmitted light in a microscope) mass with round and oval "ghost structures". Needles of calcite and siliceous sponges and foraminifers are the only recognizable micro components.

Only few elements were available for observation and measurements. Their thickness was $5-7 \mathrm{~cm}$ in the annex of the church and $2-4 \mathrm{~cm}$ in other places. The most frequent length was $45 \mathrm{~cm}$.

\section{Hard, thick platy sandstone}

Hard, thick platy sandstone was found in the Church allegedly under the invocation of St. Gereon call and in walls of the church of Tyniec convent (Bromowicz \& Magiera 2007). It is compact carbonate sandstone, very fine to coarse grained, and laminated, mainly lightgrey in colour, sometimes with yellow and reddish shades. 


\section{Petrography}

Quartz grains dominate over rare feldspars and fragments of mica schists and other siliceous and carbonate rocks. Needles of both calcite and silica sponges are quite frequent. Binder of the stone is mixed, siliceous, carbonate and argilicaeous. Carbonates form secondary coarse crystalline cement, other components form primary matrix.

Żurowska (1971) found that quality of works is much better in the apse of the Tyniec church than in its presbytery. Moreover, the size of the elements in both churches varies slightly. Their average length is generally around $23 \mathrm{~cm}$, but is slightly bigger $(26.2 \mathrm{~cm})$ in a presbytery of the Tyniec church. The thickest (average is $10.4 \mathrm{~cm}$ ) bricks were applied in the apse of the Tyniec church, while those from other walls are thinner and quite similar (average $13.5 \mathrm{~cm})$ (Tab. 1).

\section{Irregularly shaped limestone}

Irregularly shaped limestone is the most frequent among all building stones used in early mediaeval buildings in Krakow. It was used in foundations (in the St. Salvatore and St. Adalbert churches as well as in the Benedictines convent) and as a filler in walls (in the opus emplectum technique) in which external faces were built of platy varieties of sandstones and limestones. However, the most spectacular application of irregularly shaped limestone was in decorative elements of facades. Originally irregular limestone blocks were shaped to obtain regular rectangular external faces and placed into various places of walls, giving them a look very impressive and characteristic for Romanesque buildings of Krakow. They were found in many edifices, e.g. in the Romanesque Hermanowska cathedral, defence tower (Stolp), Romanesque western tower near the Smocza Jama cave (Bromowicz \& Magiera 2009), in younger (I and III) stages of the St. Salvatore church (Bromowicz 2009), in St. Adalbert church, in St. Nicholas church, in the church of the Norbertine convent and in the Dominican convent (Bromowicz \& Magiera 2006).

\section{Petrography}

Compact and fine-detritic grey and grey-brown (white on weathered surfaces) limestone dominate among examined samples of the irregularly shaped limestone. Compact pelitic or coarse-detritic limestone and less compact chalky (argilicaeous) limestone are less frequent. Mineral detritus is up to $2 \mathrm{~mm}$ in size. It is visible in microscope in transmitted light on the darker or brighter pelitic background or can be observed as positive relief on weathered surface of the stone. Small caverns of $0.5-1.0 \mathrm{~mm}$ in size are empty or filled with sparitic calcite. Varieties of the limestone differ in content of micrite and detritic material. The micrite may dominate or be present only in small amount in interstices among detritic grains.

Pelitic limestone reveals characteristic shelly surface of break. It contains very fine (up to $0.5 \mathrm{~mm}$ ) grained bioclasts and intraclasts dispersed in volume of micrite with fine peloids. 
Bioclasts, intraclasts and caverns of coarse grained limestone are up to $10 \mathrm{~mm}$ in diameter. Weathered surface is very rough due to a positive relief of large detritic grains. Some varieties are porous and less compact. Some pores and caverns are infilled with calcite sparite. Calcified sponges form interfingering structures that penetrate the whole volume of the rock.

Chalky limestone (leaves white dust on fingers) contains white bioclasts of ca. $2 \mathrm{~mm}$ in size. Microscopic analysis reveals numerous intraclasts and advanced micritisation of all components. Regularly spaced pores of $0.2-0.3 \mathrm{~mm}$ in size can be seen as well.

\section{Shape and size of blocks}

Irregular limestone clumps are generally poorly rounded and vary in size. They are $3-23 \mathrm{~cm}$ (average is $8 \mathrm{~cm}$ ) long in the foundations of the earliest (first) St. Salvatore church. Similar irregular clumps infill space between faces of the external walls and arched wall crossing the presbytery. It is possible, that limestone clumps were taken from natural scree formed at the foothill of limestone tors and cliffs. The limestone blocks in the foundations of the youngest (third) Romanesque St. Salvatore church are angular and they gradually get coarser upward, similarly to foundations of other Romanesque buildings. Average size of clumps in the lower part of the foundations of this church is $15 \mathrm{~cm}$ and it rises to $30.4 \mathrm{~cm}$ in the upper part.

The limestone clumps in the foundations of St. Adalbert church have average size $15 \mathrm{~cm}$ and reveal indistinct bedding. More prominent bedding can be seen in the foundations of the church of Tyniec monastery. The largest limestone blocks (up to $90 \mathrm{~cm}$ of length) of all observed edifices are laid down in layers.

Average height and length of limestone clumps of the walls of early mediaeval Krakow edifices are, respectively, $10.4-15.7 \mathrm{~cm}$ and 15.9-27.4. The largest are in the refectory of the Dominican convent. The most irregular (elongated) are elements of the walls of St. John, the most isometric - those of the walls of the Norbertine convent. The latter are generally the largest of all examined wall blocks.

Four groups of edifices can be distinguished based on the size of the limestone wall blocks. The first group - with the smallest blocks - consists of the Hermanowska cathedral and third church of St. Salvatore. Second group comprises the Stolp, first church of St. Salvatore, St. Andrew church, and church of St. Nicholas. Churches of St. John and St. Adalbert form third while the Norbertine and Dominican convents the fourth group (Tab. 2).

Standard deviation points to high uniformity of the limestone block size in the St. Salvatore church, contrary to the Dominican refectory, where variability of size is the greatest. In other edifices size of limestone blocks are not significantly differentiated. Due to aesthetic standards two basic heights were applied commonly. This does not reflect in standard deviation: the length varies slightly more than the height. 
Table 2

Size of limestone irregular clumps in the early mediaeval edifices of Krakow

\begin{tabular}{|c|c|c|c|c|c|}
\hline \multirow{2}{*}{ Edifice } & \multirow{2}{*}{$\begin{array}{c}\text { Number } \\
\text { of } \\
\text { measurements }\end{array}$} & $\begin{array}{c}|c| \\
\text { average } \\
{[\mathrm{cm}]}\end{array}$ & $\begin{array}{c}\text { Height } \\
\text { deviation } \\
{[\mathrm{cm}]}\end{array}$ & $\begin{array}{c}\text { Length } \\
\text { average } \\
{[\mathrm{cm}]}\end{array}$ & $\begin{array}{c}\text { standard } \\
\text { deviation } \\
{[\mathrm{cm}]}\end{array}$ \\
\hline $\begin{array}{c}\text { Romanesque cathedral } \\
\text { (Hermanowska cathedral) }\end{array}$ & 1067 & 10.4 & 3.3 & 17.7 & 6.8 \\
\hline defence tower (Stolp) & 377 & 12.2 & 3.6 & 18.3 & 8.1 \\
\hline $1^{\text {st }}$ church of St. Salvatore & 44 & 12.4 & 1.7 & 21.3 & 4.5 \\
\hline $3^{\text {rd }}$ church of St. Salvatore & 2718 & 10.6 & 4.2 & 15.9 & 6.7 \\
\hline St. John church* & 161 & 13.7 & 3.3 & 23.4 & 7.4 \\
\hline St. Adalbert church & 123 & 14.4 & 3.7 & 22.4 & 8.2 \\
\hline St. Andrew church & 201 & 11.9 & 2.4 & 18.4 & 7.9 \\
\hline St. Michael church** & 57 & 11.0 & 2.2 & 19.7 & 5.6 \\
\hline Norbertine convent & 68 & 17.1 & 5.0 & 21.8 & 8.7 \\
\hline Dominican convent & 1164 & 15.7 & 6.5 & 27.4 & 14.3 \\
\hline
\end{tabular}

Elements were measured by the authors in situ or on drawings of walls in:

*Hendel \& Kopera (1906) and **Rojkowska \& Niewlada (2005).

\section{Soft dimension sandstone}

Soft dimension sandstone is susceptible to shaping and carving. Its bedding is thick and very thick (up to several metres) and allows for excavating large blocks of high volume. They were commonly used as a reinforcing construction material in edges of walls. Less frequently they were used as wall constructing material, in single or multiple layers (e.g., the Stolp and third church of St. Salvatore, respectively) and for cutting and carving tombstones, columns, portals or elements of altars.

Soft dimension sandstone was found in the walls of the Romanesque cathedral (Tower of Silver Bells), defence tower (the Stolp), churches of St. Salvatore, St. Andrew and St. Nicholas and convents of Norbertine and Dominican. Moreover, they were reported from the walls of the Church located near the Sandomierska tower and from the walls of St. Mary's church, but actually not exposed to the observation. Minor architectonic elements carved in the soft sandstone were found in all those edifices as well as in the church allegedly under the invocation of St. Gereon call and in the Benedictine convent, in some of Pre-Romanesque buildups (Chrobrowska cathedral, "B" church) (Bromowicz \& Magiera 2009). Actually not available for examination but reported in publications (Rajman 1994, Świechowski 2000) are sandstone elements in St. Benedict church and in St. Mary's church. 


\section{Petrography}

Soft sandstone varies in colour from greyish with pink or yellow shades to brown, dark grey or even black-grey. Grain size varies too from fine (less than $0.5 \mathrm{~mm}$ ) to medium $(0.5-2.0 \mathrm{~mm}$ ) and coarse (above $2 \mathrm{~mm}$ ) of diameter. Grain size fraction $0.1-0.3 \mathrm{~mm}$ dominates in all varieties. Most frequent sandstone is fine grained and grey and yellowish-grey in colour. Coarse grained variety is relatively very rare.

Sandstone is essentially not very hard but very porous. Grains contact closely and form quite compact framework. Quartz grains dominate, less frequent are feldspars (up to $10 \%$ of all grains), biotite, pyrite, glauconite and silty pebbles (or caverns after them), well visible even with naked eye. Rare biogenic tunnels are up to $10 \mathrm{~mm}$ in diameter. Muscovite, chlorite and rounded fragments of mica and chlorite schists, gneiss and granite can be seen under a microscope. Clayey-argillaceous binder is scarce and normally free of carbonates.

\section{Shape and size of blocks}

The largest sandstone blocks (average height: $33.9 \mathrm{~cm}$, average length: $64.7 \mathrm{~cm}$ ) were found in the Tower of Silver Bells. They have roughly half of this size in other examined buildings (Tab. 3).

Table 3

Size of soft sandstone blocks in the early mediaeval edifices of Krakow

\begin{tabular}{|c|c|c|c|c|c|}
\hline \multirow{2}{*}{ Edifice } & \multirow{2}{*}{$\begin{array}{c}\text { Number } \\
\text { of } \\
\text { measurements }\end{array}$} & $\begin{array}{c}|c| \\
\text { average } \\
{[\mathrm{cm}]}\end{array}$ & $\begin{array}{c}\text { Standard } \\
\text { deviation } \\
{[\mathrm{cm}]}\end{array}$ & $\begin{array}{c}\text { Length } \\
\text { average } \\
{[\mathrm{cm}]}\end{array}$ & $\begin{array}{c}\text { standard } \\
\text { deviation } \\
{[\mathrm{cm}]}\end{array}$ \\
\hline $\begin{array}{c}\text { Romanesque cathedral } \\
\text { (Hermanowska cathedral) } \\
\text { Tower of Silver Bells }\end{array}$ & $13^{*}$ & 33.9 & 9.3 & 64.7 & 10.6 \\
\hline defence tower (Stolp) & 31 & 18.4 & 2.4 & 33.9 & 13.7 \\
\hline $3^{\text {rd }}$ church of St. Salvatore & 380 & 25.8 & 9.4 & 36.0 & 17.4 \\
\hline St. Andrew church & 24 & 21.1 & 4.9 & 33.7 & 14.7 \\
\hline Norbertine convent & 20 & 20.7 & 4.6 & 26.8 & 8.3 \\
\hline Dominican convent & 78 & 21.1 & 7.6 & 35.0 & 14.5 \\
\hline
\end{tabular}

*Only the longest edges were measured in SW edge of the tower.

\section{PROVENANCE AND QUARRYING CONDITIONS OF BUILDING STONES IN EARLY MEDIAEVAL EDIFICES IN KRAKOW}

Examined early mediaeval edifices in Krakow mark a very important stage of development of historical Polish architecture: beginning of mining and application of stone. 


\section{Sandstones (Carpathian flysch)}

Bromowicz \& Magiera (2008) estimated that ca. $340 \mathrm{~m}^{3}$ or $792 \mathrm{~m}^{3}$ of hard, thin plated sandstone was used for construction of Felix and Adauct church, depending on the reconstruction mode (according to, respectively, Szyszko-Bohusz or Żurowska \& Węcławowicz, both in: Pianowski 1994). Together with other buildings, where similar material was used as well as younger edifices, where such sandstone was re-used after demolishing earlier constructions, they point to rather large volume of stone material that was excavated and used. Szyszko-Bohusz (1918) expected that exploitation took place in area SE of Wieliczka. Indeed, later investigations by Burtan (1954), Bober et al. (1961), S.W. Alexandrowicz (1973) and Magiera (1976) confirmed, that natural outcrops of the Gaize, Grodziszcze and Lgota beds in the Sub-Silesian nape and in the front part of the Silesian nape (Carpathian flysch) were sources of the hard thin and thick plated sandstone.

Thickness of the sandstone plates increases consequently in younger (Romanesque) buildings. This was possibly due to development of exploitation. Sandstone, in particular with laminated structure, has a susceptibility to split into thin plates in outcrops or in superficial beds. It is caused by mechanical rheological relaxation. Therefore, thin plated sandstone elements are easily available in natural outcrops or in slope scree (Fig. 3).

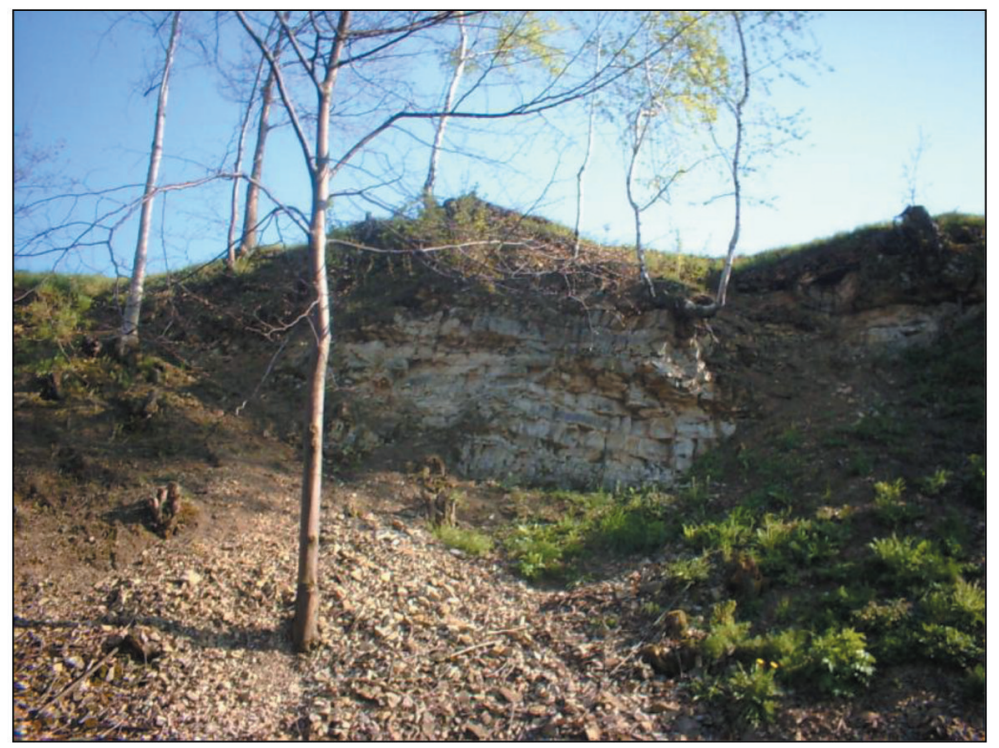

Fig. 3. Outcrop (disused quarry) of the gaize sandstone and a scree talus, located near Koźmice Wielkie, SE of Wieliczka

As the excavation proceeded and deeper parts of rock were reached its susceptibility to splitting into thin plates reduced and thicker elements (thick plated sandstone) became available. 
Bromowicz \& Magiera (2003) suggest moreover, that thin plated hard sandstone was originally used in earlier, Pre-Romanesque ramparts of fortified settlements, like, e.g. in Poznachowice and were next reused in younger edifices after demolishing the earlier ones. Ramparts were constructed as dry walls, without mortar. It considerably facilitated this specific "recycling".

Soft sandstones were excavated in the Carpathians too. They represent Istebna or Ciężkowice sandstone. They cannot be distinguished from one another in samples, without geological observations in outcrops. However, it is more probable that it is the Istebna sandstone which is commonly present in early mediaeval edifices in Krakow. Its outcrops are located much closer to the city and are much larger than outcrops of the Ciężkowice sandstone. They stretch between Świątniki and Dobczyce on large area just S of above mentioned exposures of the Grodziszcze, Lgota and Gaize sandstones. The stone was excavated possibly again in the area $\mathrm{S}$ of Wieliczka, as this was a traditional masonry region those times while exposures in other areas were much less accessible.

Within both, Pre-Romanesque and Romanesque edifices there are many tombstones, columns and other large stone elements that apparently required quarrying and working bulky stone blocks. Most impressive are eight columns in St. Leonard's crypt, the most eminent sacral edifice of Poland that time. They point to the great role played by masonry of large volume stone blocks in raising the prestige of edifices. The columns have slightly different diameters which probably reflect difficulties in obtaining suitable and uniform large blocks. According to opinion expressed by Bromowicz (2009) such large blocks could have been quarried in sandstone tors which are numerous on the exposures of the Istebna sandstone S of Krakow (Z. Alexandrowicz 1978) but in larger distance from the city. The tors located closer to it could have been totally exploited.

\section{Limestone (Upper Jurassic)}

All the limestone blocks found in the early mediaeval edifices in Krakow were quarried from the Jura area with the city limits or N and NW of Krakow. Total thickness of the Upper Jurassic carbonates reaches $250 \mathrm{~m}$ there.

Tectonic framework of the Jura controls pattern of the Jurassic limestone exposures within Krakow and in close vicinity of it. They are splitted into blocks (horsts) separated by depressions (grabens) infilled with Miocene clay. The horsts form hills, e.g. the Wawel Hill, Skałka, Krzemionki, Zakrzówek, Las Wolski.

Facial varieties of the limestone are well exposed within the hills and were the source of limestone building material for early mediaeval edifices. Their compactness and bedding differ, which results in various productivity of different stone elements. Rocky and bedded Jurassic limestone yielded irregular blocks and clumps. However, bedded limestone splits much better into cuboidal bricks than the rocky limestone and, therefore, was a main source of limestone bricks. Platy limestone was a rich source of thin platy elements. Chalky limestone in turn are a very good material for sculpture, but their occurrences are limited 
and they almost do not reveal any block divisibility, thus stone elements made of them are very rare.

Number and volume of the edifices point to a very large volume of limestone quarried and to massive changes in a landscape of the city that time, much larger than in the Carpathians $\mathrm{S}$ of it.

The oldest document on the exploitation of the Jurassic limestone is dated to 1375 (Kutrzeba 1899) and points to the Krzemionki Hill. The oldest quarry was probably located below St. Benedict church, just aside of very important Wieliczka track. Limestone blocks quarried there were used in reconstruction of this Romanesque (at that time) church (Rajman 1994, Szczepańska 2005). Other, younger quarries were located near or in the place where actually Redemptorists church is situated (in the W part of the Krzemionki Hill), in the actual Bednarski Park or near St. Josef church (in the central part of the hill). Swaryczewski (1977) suggested that dimension stone could have been excavated there. This was confirmed by Szczepańska (2005). Bromowicz \& Magiera (2008) estimated that ca. $27,000 \mathrm{~m}^{3}$ of stone was excavated by 1857 (totally ca. $124,000 \mathrm{~m}^{3}$ during the whole period of its productivity till the closure of the quarry in 1960s).

The oldest ever places of excavation of the Jurassic limestone were probably located within the Wawel Hill where all three main facies varieties occurred in the past. However, there are no direct evidences of this opinion. Hilltop, built of platy limestone, was probable exploited first. When easily quarrable platy limestone exhausted, bedded and rocky limestones were excavated on the hill slopes. Some slopes are nearly vertical. They probably are not natural but shaped by human mining activity.

Similar early quarrying took probably place within the Skałka Hill and near St. James church (Bromowicz \& Magiera 2009) as well as within the Zakrzówek Hill, relatively easily accessible by a ford on the Vistula River located at the Skałka foothill. Exploitation of the Jurassic limestone within the Lasek Wolski Hill and in Mydlniki (E edge of the Tęczynek ridge) is only theoretically considered. It is worthy pointing that there are no serious natural obstacles, like rivers or cliffs on the way between the city centre and those two localities.

\section{CONCLUSIONS}

1. Two varieties of limestone and three varieties of sandstone were used as building material in early mediaeval edifices of Krakow. They naturally split in elements of various shape and size, except for rocky limestone, which yields irregular clumps.

2. Only local material was used: Upper Jurassic limestones of the $\mathrm{S}$ edge of the Krakow-Częstochowa Jura and sandstones of the Carpathian flysch of Cretaceous to Palaeogene age.

3. Quarries were located within a radius of ca. $15 \mathrm{~km}$ from the city centre.

4. Building material of the earliest edifices was acquired from natural and easily mineable scree and from tors. 
5. Early buildings were raw (e.g. Church of St. Felix and Adauct). Later, different stone varieties were used deliberately to obtain desired aesthetic effect (e.g. church allegedly under the invocation of St. Gereon call and the church of Tyniec Monastery).

6. Skill of shaping bedded limestone into regular cuboid bricks was a milestone in development of early mediaeval masonry and architecture.

7. Sources of building stones became more distant from the city with time, as closer sources exhausted, but the volume of stone blocks increased too. This is an apparent result of developing of skills of quarrying, stone working and transport.

\section{REFERENCES}

Alexandrowicz S.W., 1973. Gaize-types sediments in the Carpthians flysch. Neues Jahrbuch für Geologie und Paläontologie (Monatschefte), 1, 1-17.

Alexandrowicz Z., 1978. Skałki piaskowcowe zachodnich Karpat fliszowych [Sandstone tors of the Western Flysch Carpathians]. Prace Geologiczne Komisji Nauk Geologicznych PAN w Krakowie, 113, 5-87 [with English summary].

Bober L., Badak J. \& Kita-Badak M., 1961. O możliwości wykorzystania piaskowców z warstw gezowych miedzy Mogilanami a Wieliczką [On the feasibility of utilizing the sandstones from the gaize beds in the region of Wieliczka]. Kwartalnik Geologicz$n y, 5,3$ [with English summary].

Bromowicz J., 2009. Pochodzenie kamienia z kolumn krypty św. Leonarda na Wawelu [The origin of stone from columns in the St. Leonard's crypt (the Wawel cathedral)]. Prace Naukowe Instytutu Górnictwa Politechniki Wrocławskiej, 121, 19-36 [with English summary].

Bromowicz J. \& Magiera J., 2003. Pochodzenie piaskowców z murów wawelskiej rotundy św. św. Feliksa i Adaukta. Konferencja Naukowa „,Kamień architektoniczny i dekoracyjny”, Kraków AGH, 23-24 września 2003 r., 13-20.

Bromowicz J. \& Magiera J., 2006. Znajomość litologii piaskowca pomocą w rekonstrukcjach architektonicznych romańskich budowli na przykładzie refektarza klasztoru oo. Dominikanów w Krakowie [The lithology of the building stones as a key to architectural reconstruction. A case study of the romanesque refectory of the Domincan Convent in Krakow]. Górnictwo Odkrywkowe, 1-2, 54-60 [with English summary].

Bromowicz J. \& Magiera J., 2008. Geologiczno-górnicza problematyka złóż kamienia dla budowli wczesnośredniowiecznego Krakowa [Stones used in early mediaeval Krakow buildings. Geological and mining issues]. Górnictwo Odkrywkowe, 3-4, 45-49 [with English summary].

Bromowicz J. \& Magiera J., 2009. Stones of Early Mediaeval buildings of the Wawel Hill (Cracow, Poland). Acta Archeologica Waweliana, IV, 1-52. 
Bromowicz J. \& Magiera J., 2010. Badania geologiczne materiałów kamiennych wczesnośredniowiecznych budowli Krakowa [Geological investigations of stonework of early mediaeval buildings in Krakow]. Biuletyn PIG, 439, 425-436 [with English summary].

Burtan J., 1954. Mapa geologiczna Polski 1:50 000. Arkusz Wieliczka [Geological map of Poland. Sheet Wieliczka]. Państwowy Instytut Geologiczny, Warszawa.

Burtan J., 1984. Tektonika Karpat fliszowych na południe od Wieliczki [The tectonics of of the flysch Carpathians south of Wieliczka]. Biuletyn IG, 340, 7-22 [with English summary].

Burtan J., Golonka J., Oszczypko N., Paul Z. \& Ślączka A., 1981. Mapa geologiczna Polski 1:200 000, arkusz Nowy Sacz [Geological map of Poland, 1: 200 000, Sheet Nowy Sącz]. Państwowy Instytut Geologiczny, Warszawa.

Caileux L., 1929. Les roches sédimentaires de France. Roches siliceuses. Ministère des travaux publics, Paris.

Firlet J. \& Pianowski Z., 1978. Wyniki badań nowoodkrytego kościoła romańskiego w zachodniej części Wawelu. Sprawozdania z Posiedzeń Komisji Naukowych PAN, Oddziat w Krakowie, 22, 17-18.

Firlet J. \& Pianowski Z., 1985. Sprawozdanie z badań w podziemiach katedry wawelskiej 1981-1983 r. Odkrycie kościoła przedromańskiego. Stan badań nad wczesnośredniowiecznymi kościołami katedralnymi na Wawelu [Report on the 1981-983 investigations in the vaults of the Wawel cathedral. Doscovery of a Pre-Romanesque church]. Sprawozdania Archeologiczne, 37, 169-179 [with English summary].

Golonka J., Borysławski A., Paul Z. \& Ryłko W., 1978. Mapa geologiczna Polski 1:200 000, arkusz Bielsko-Biała [Geological map of Poland, 1: 200 000, Sheet Bielsko-Biała]. Państwowy Instytut Geologiczny, Warszawa.

Gradziński R. \& Gradziński M., 1994. Budowa geologiczna i rzeźba [Geology and relief of the Cracow area]. [in:] Gradziński R., Gradziński M. \& Michalik S., Natura i kultura w krajobrazie jury. T. 3: Przyroda, Zarząd Zespołu Jurajskich Parków Krajobrazowych, Kraków, 13-54 [with English summary].

Hendel Z. \& Kopera F., 1906. Resztki murów romańskich kościoła św. Jana w Krakowie. Rocznik Krakowski, 9, 209-212.

Jurkiewicz H. \& Woiński J., 1977. Mapa geologiczna Polski 1:200 000, arkusz Tarnów [Geological map of Poland, 1:200 000, Sheet Tarnów]. Państwowy Instytut Geologiczny, Warszawa

Kaziuk H. \& Lewandowski J., 1978. Mapa geologiczna Polski 1:200 000, arkusz Kraków [Geological map of Poland, 1:200 000, Sheet Kraków]. Państwowy Instytut Geologiczny, Warszawa.

Kozieł S., 1998. Technologia murów budowli przedromańskich na Wawelu [Technology employed in the walls of Pre-Romanesque structures on the Wawel Hill]. Acta Archeologia Waweliana, 2, 55-78 [with English summary].

Książkiewicz M., 1972. Budowa geologiczna Polski. T. 4: Tektonika. Cz. 3: Karpaty. Wydawnictwa Geologiczne, Warszawa. 
Kutrzeba S., 1899. Finanse Krakowa $w$ wiekach średnich. Kraków.

Magiera J., 1976. Piaskowce z warstw gezowych. [in:] Bromowicz J. \& Peszat C. (red.), Piaskowce karpackie, ich znaczenie surowcowe i perspektywy wykorzystania [The Carpathian sandstones, their significance as raw materials and perspectives of their utilization], Zeszyty Naukowe Akademii Górniczo-Hutniczej im. Stanisława Staszica: Geologia, 2 (2), 3-95 [with English summary].

Magiera J. \& Michalczyk W., 2000. Przestrzenna analiza parametrów czwartorzędowych kruszyw naturalnych w rejonie Krakowa [Deposits of the Quaternary natural aggregates in the Krakow region - spatial analysis of parameters]. Zeszyty Naukowe Akademii Górniczo-Hutniczej im. Stanisława Staszica: Geologia, 26 (1), 68-89 [with English summary].

Matyszkiewicz J., 1997. Microfacies, sedimentation and some aspects of diagenesis of Upper Jurassic sediments from the elevated part of the Northen peri-Tethyan Shelf: a comprative study on the Lochen aera (Shwäbische Alb) and Cracow aera (CracowWieluń Upland, Poland). Berliner Geowissenschafttliche Abhandlungen, E 21, 1-111. Pianowski Z., 1991. Wawel obronny. Zarys przemian fortyfikcji grodu i zamku krakowskiego w. IX-XIX [Wawel fortifications. An outline of changes in the defence system of Wawel Hill between $9^{\text {th }}$ and $19^{\text {th }}$ centuries]. Biblioteka Wawelska, 8, 1-179 [with English summary].

Pianowski Z., 1994. „Sedes regni principales” - Wawel i inne rezydencje piastowskie do połowy XIII wieku na tle europejskim. Monografia - Politechnika Krakowska im. Tadeusza Kościuszki. Architektura, 178, 1-217.

Rajman J., 1994. Mons ante Cracoviam. Najdawniejsze dzieje kościoła św. Benedykta na górze Lasoty [Monts ante Cracoviam. Earliest history of St. Benedict's church in Krzemionki]. Rocznik Krakowski, 50, 5-20 [with English summary].

Rojkowska H. \& Niewlada W., 2005. Kościół św. Mikołaja w Krakowie w świetle ostatnich badań (1995-1997). [in:]: Gadomski J. et al. (red.), Lapides Viventes. Zaginiony Kraków wieków średnich. Księga dedykowana profesor Klementynie Żurowskiej, Instytut Historii Sztuki Uniwersytetu Jagiellońskiego, Wydawnictwo Uniwersytetu Jagiellońskiego, Kraków, 159-169.

Rutkowski J., 1989. Budowa geologiczna regionu Krakowa [Geological structure of the Cracow region, South Poland]. Przeglad Geologiczny, 6, 302-308 [with English summary].

Rutkowski J., 1993. Objaśnienia do Szczegółowej mapy geologicznej Polski 1:50 000. Arkusz Kraków (973). Państwowy Instytut Geologiczny, Warszawa.

Swaryczewski A., 1977. Historyczne zmiany układu przestrzennego Krzemionek krakowskich [Historical changes in the development of the Krzemionki Hill by Cracow]. Teka Komisji Urbanistyki i Architektury, 11, 5-16 [with English summary].

Szczepańska M., 2005. Przegląd wyrobisk górniczych Krzemionek Podgórskich. [in:] Szczepańska M. \& Pilecka E. (red.), Geologiczno-przyrodnicze rozpoznanie terenów pogórniczych Krzemionek Podgórskich dla potrzeb ochrony ich wartości naukowo-dydaktycznych i ekologicznych, Wydawnictwo IGSMiE PAN, Kraków, 43-59. 
Szyszko-Bohusz A., 1918. Kościół świętych Feliksa i Adaukta (Najśw. Panny Marii) na Wawelu. Rocznik Krakowski, 18, 53-79.

Świechowski Z., 2000. Architektura romańska w Polsce [Romanesque architecture in Poland]. DiG, Warszawa [with English summary].

Żaki A., 1959. Karpacka ekspedycja archeologiczna w latach 1951-1955 [Archeological explorations in the Carpathians between 1951 and 1955]. Sprawozdania Archeologiczne, 5 [with English summary].

Żurowska K., 1971. Romański kościół opactwa benedyktynów w Tyńcu [L’abbotial Romane des Benedictins à Tyniec]. Folia Historiae Artium, 6-7, 49-119 [with French summary]. 